\author{
(online) $=$ ISSN $2285-3642$ \\ ISSN-L = $2285-3642$ \\ Journal of Economic Development, Environment and People \\ Volume 9, Issue 1, 2020 \\ URL: http://jedep.spiruharet.ro \\ e-mail: office jedep@spiruharet.ro
}

\title{
Ecotourism; Implementation of Security Management Concepts
}

\author{
Dhian Tyas Untari ${ }^{1}$ \\ ${ }^{1}$ Bhayangkara Jakarta Raya University, Indonesia
}

\begin{abstract}
The following paper is an essay; base on book review it examines and links the concept of ecotourism and the concept of security management. It is hoped that this essay will become a new topic for academics and practitioners. At present, ecotourism and the concept of security management are known and developed separately, there has never been a study that tries to link the two concepts. Ecotourism is only understood as the concept of protection of biodiversity, whereas security management is only perceived as a concept of physical security which is then associated with defending the country and building a soul of nationalism. This study seeks to provide a broad picture of security management so that it can understand that the concept of security is very broad, including how to protect the diversity of biodiversity that is owned through the development of Ecotourism.
\end{abstract}

Keywords: Security management, Ecotourism, Community based tourism, Sustainability

JEL Codes: O53, O57, Z32

How to cite: Untari, D.T. (2020)-Ecotourism; Implementation of Security Management Concepts. Journal of Economic Development, Environment, and People, 9(1), doi: http://doi.org/10.26458/jedep.v9i1.646

\section{Introduction}

The concept of security from many literature reviews understanding is an attempt to secure assets to eliminate threats and losses. As Sheryl Strauss (1980) stated, its broadest sense, security is the prevention of loses of all kinds, from whatever causes, whereas Rick (1994) stated that security is defined as the protection of assets from loss

Ecotourism is a form of implementation of the concept of security management. The implementation of the concept of security management is not only in the concept of securing state assets or securing physical territory, not only within the scope of office management. But more broadly, the concept of security management must be implemented in an effort to secure the resources owned by a country, so that in the future natural resources and social resources owned can be sustainable and enjoyed by future generations. Massive exploitation of the resources owned by an area, ecological damage which will then have a negative impact on living things. This is where the security values must be implanted, understood and implemented. 


\author{
(online) = ISSN $2285-3642$ \\ ISSN-L = 2285 - 3642 \\ Journal of Economic Development, Environment and People \\ Volume 9, Issue 1, 2020 \\ URL: http://jedep.spiruharet.ro \\ e-mail: office jedep@spiruharet.ro
}

\title{
2. General Concept of Security Management
}

The concept of security from several literature reviews understanding is an attempt to secure assets to eliminate threats and losses. Robert McCrie (2001: 5) Provides a definition of security that is security is defined as the protection of assets from loss (security is an effort to provide protection for assets/assets to avoid loss). From the initial understanding of security has a broad dimension, depending on what field the word security is used. Security Management is a system to provide a complete and integrated understanding, supported by the ability and skills to plan and design an appropriate, effective and efficient Security System, in accordance with the situations and conditions encountered and useful to prevent losses as early as possible.

Gigliotti and Jason (1984) categorize security efforts according to the levels of security management. There are 5 (five) levels of the security system, namely:

1. Level 1 is the minimum level of security, a system that is designed to deter/obstruct some unauthorized external activity interruption with the main equipment in the form of simple physical barriers and simple lock.

2. Level 2 is low-level security, which is a security system that is designed to deter/obstruct and detect some interference from unauthorized activities from outside with the main equipment in the form of basic local alarm security, simple security lighting, basic physical security barrier and a high-security lock.

3. Level 3 is a medium security, which is a system that must be designed to deter/intervene, detect and assess/assess unauthorized internal interference activities such as theft that leads to conspiracy to sabotage with the main equipment in the form of advance remote alarm system, a high-security physical barrier at the perimeter, guard dogs and watchman with basic communication.

4. Level 4 is high-level security, a separation system that is designed to deter/obstruct, detect and assess/assess large disturbances originating from inside or outside with basic equipment in the form of CCTV, perimeter alarm system, highly trained alarm guards with advance communication, access controls, high-security lighting, local low enforcement coordination, and formal contingency plans.

5. Level 5 is maximum security that is a system designed to deter/obstruct, detect and estimate/assess and neutralize all disturbances from both outside and inside activities with the main equipment in the form of on-site armed response force, sophisticated alarm system.

\section{Implementation of Security Management}

The concept of Ecotourism has begun to be widely implemented in several countries, as well as in Indonesia. Where Indonesia is one of the countries in the world that has natural wealth and biodiversity diversity. In fact, currently, the development of ecotourism-based tourism is still questionable, whether developed tourism has met the rules of ecotourism governance or only nature-based tourism.

The development of nature-based tourism which then over-exploits nature will give a negative impact on ecological sustainability in it. Talking about ecology is not only limited to discussing the mutual 


\author{
(online) $=$ ISSN $2285-3642$ \\ ISSN-L = $2285-3642$ \\ Journal of Economic Development, Environment and People \\ Volume 9, Issue 1, 2020 \\ URL: http://jedep.spiruharet.ro \\ e-mail: office jedep@spiruharet.ro
}

relationship between biotics and abiotics, but more broadly, ecology includes human relations with other humans both individually and communally (Untari, 2017). Through the development of ecotourism, it is hoped that the tourism sector can have a negative impact by minimizing negative impacts both economically, socio-culturally and ecologically.

Iwan Nugroho's book entitled "Ecotourism and Sustainable Development: (2011) states that the term ecotourism was first introduced by" The International Ecotourism Society in 1991, namely a kind of tourism with a natural environment that is still original concerning its cultural and natural heritage, thus ecotourism is a biotic and abiotic environment based tour, photographing its interactions and preserving so that its existence can continue to be sustainable.

The implementation of ecotourism activities is not only limited to the natural environment. But more than that, ecotourism can be implemented as a form of conservation of cultural products; which is the creation of human tastes and works as well as historical products. Socio-cultural and historical products are a reflection of human interaction with other humans both individually and communally. This interaction is known as human ecology (Untari, 2017).

The concept of mass tourism which is oriented towards the number of visitors causes a decrease in the quality of service, a decrease in visitor satisfaction and more certain is a decline in the quality of the ecological environment of the tourist destination. So we need certain restrictions that can be implemented so that tour managers can control the number of visits, maintain service quality and visitor satisfaction. In the concept of ecotourism, there are several terms known as; Recreational Opportunity Spectrum (ROS), Limits of Acceptable Change (LAC), Visitor Impact Management (VIM) and Visitor Activity Management Process (VAMP). In the management of ecotourism, the concept must be considered to preserve the tourism resources owned.

In addition to the protection of ecology, the concept of ecotourism encourages community participation to participate in managing tourist destinations. By prioritizing community participation, the community will automatically build a sense of belonging to the tourist destination, so that it is hoped that the community can participate in maintaining and preserving ecotourism products. Also, by developing community-based tourism, it is expected to improve the economy of the local community and be followed by an increase in the welfare of the community. In the concept of privatization of tourist destinations, it often just makes the public as a spectator, without getting socio-economic impact. In fact, in some cases, the community is only just a target market.

\title{
4. Conclusion
}

In conclusion, the concept of ecotourism is the concept of tourism that must be developed, given the magnitude of the natural damage that has occurred at this time and the massive exploitation of the resources owned by biodiversity diversity and the negative impacts of shifting socio-cultural values. This shift in socio-cultural values which then degrades the cultural values that exist in one region and is very likely to eliminate its local value. Through the development of ecotourism, it is expected to inspire public 


\author{
(online) $=$ ISSN $2285-3642$ \\ ISSN-L = 2285 - 3642 \\ Journal of Economic Development, Environment and People \\ Volume 9, Issue 1, 2020 \\ URL: http://jedep.spiruharet.ro \\ e-mail: office jedep@spiruharet.ro
}

awareness about the value of conservation; protection, preservation, and utilization of available resources related to physical and social-cultural assets. The concept of security management is not only related to mere physical security, but broader security management protects the region or country from losing valuable assets, namely the wealth of resources and biodiversity.

\title{
5. References
}

[1] Iwan Nugroho. 2011. Ekowisata dan Pembangunan Yang Berkelanjutan. Kementrian Pariwisata; Indonesia

[2] Rick, Truett A. 1994. Principles of Security, 3ed edition. Ohio, Anderson Publisher co.

[3] Sheryl Strauss. 1981. Security Problem in a Modern Society. Boston, Butterworth Publisher Inc.

[4] Untari, Dhian Tyas. Avenzora, Ricky. Darusman, Dudung. Prihatno, Joko. 2017. Betawi Traditional Cuisines; Reflection the Native Culture of Jakarta (Formerly Known as Batavia). Journal of Economic Development Environment and People. 6(4), 64-76 